\title{
Chemical Constituents of Cassia abbreviata and Their Anti-HIV-1 Activity
}

\author{
Xianwen Yang ${ }^{1,2}{ }^{\mathbb{D}}$, Zhihui He ${ }^{2}$, Yue Zheng ${ }^{1,3}$, Ning Wang $^{1}$, Martin Mulinge ${ }^{3,4} \mathbb{D}$, Jean-Claude Schmit ${ }^{3,5}$, \\ André Steinmetz ${ }^{1}$ and Carole Seguin-Devaux ${ }^{3, *}$
}

1 Laboratory of Cellular and Molecular Oncology, Luxembourg Institute of Health, L-1445 Luxembourg, Luxembourg; yangxianwen@tio.org.cn (X.Y.); yue.zheng@path.utah.edu (Y.Z.); nwangmd@yahoo.com (N.W.); asteinme@pt.lu (A.S.)

2 Key Laboratory of Marine Biogenetic Resources, Third Institute of Oceanography, Ministry of Natural Sources, 184 Daxue Road, Xiamen 361005, China; hezhihui@tio.org.cn

3 Department of Infection and Immunity, Luxembourg Institute of Health,

L-4354 Esch-sur-Alzette, Luxembourg; mmulinge@uonbi.ac.ke (M.M.); jean-claude.schmit@ms.etat.lu (J.-C.S.)

4 Department of Biochemistry, School of Medicine, University of Nairobi, Nairobi P.O. Box 30197-00100, Kenya

5 Service National of Infectious Diseases, Centre Hospitalier de Luxembourg,

L-1210 Luxembourg, Luxembourg

* Correspondence: Carole.Devaux@lih.lu

Citation: Yang, X.; He, Z.; Zheng, Y.; Wang, N.; Mulinge, M.; Schmit, J.-C.; Steinmetz, A.; Seguin-Devaux, C. Chemical Constituents of Cassia abbreviata and Their Anti-HIV-1 Activity. Molecules 2021, 26, 2455. https://doi.org/10.3390/ molecules 26092455

Academic Editor: Raphaël E. Duval

Received: 1 April 2021

Accepted: 21 April 2021

Published: 23 April 2021

Publisher's Note: MDPI stays neutral with regard to jurisdictional claims in published maps and institutional affiliations.

Copyright: (c) 2021 by the authors. Licensee MDPI, Basel, Switzerland. This article is an open access article distributed under the terms and conditions of the Creative Commons Attribution (CC BY) license (https:// creativecommons.org/licenses/by/ $4.0 /)$.

\begin{abstract}
Three new (1-3) and 25 known compounds were isolated from the crude extract of Cassia abbreviata. The chemical structures of new compounds were established by extensive spectroscopic analyses including 1D and 2D NMR and HRESIMS. Cassiabrevone (1) is the first heterodimer of guibourtinidol and planchol A. Compound 2 was a new chalcane, while 3 was a new naphthalene. Cassiabrevone (1), guibourtinidol-( $4 \alpha \rightarrow 8)$-epiafzelechin (4), taxifolin (8), oleanolic acid (17), piceatannol (22), and palmitic acid (28), exhibited potent anti-HIV-1 activity with $\mathrm{IC}_{50}$ values of $11.89 \mu \mathrm{M}$, $15.39 \mu \mathrm{M}, 49.04 \mu \mathrm{M}, 7.95 \mu \mathrm{M}, 3.58 \mu \mathrm{M}$, and $15.97 \mu \mathrm{M}$, respectively.
\end{abstract}

Keywords: Cassia abbreviata; Fabaceae; anti-HIV; heterodimer; flavonoid

\section{Introduction}

Cassia abbreviata is a small-to-medium-sized branched tree of the Fabaceae. It is widely spread in the tropics, especially in southeast Africa, with a long history in traditional medicine for the treatment of numerous conditions [1], such as headaches, diarrhea, constipation, some skin diseases, malaria, syphilis, pneumonia, stomach troubles, uterine pains, and gonorrhea [2,3]. Pharmacological studies indicated that C. abbreviata showed a broad spectrum of biological activities, including CNS depression [4], hypoglycemia [5], anti-AIDS [6], hepatoprotection [7], antioxidant [8], antibacterial [9], etc. Although some fatty acid compositions were analyzed from its seed oil by gas chromatography (GC) [10], while several dimeric and trimeric flavonoids were proposed on the basis of the UPLC-MS spectroscopic data [11], the chemical component investigation on C. abbreviata was seldom reported. Up to now, only a new flavan [12] and two novel trimeric proanthocyanidins [9] were isolated.

Recently, we screened several crude extracts from different plants of Cassia species and found that C. abbreviata showed potent anti-HIV-1 activity. Therefore, a systematic phytochemical investigation was carried out, which led to the isolation of three new (1-3) and 25 known (4-28) compounds (Figure 1). Herein, we report the isolation, structure, and anti-HIV-1 activity of these compounds. 


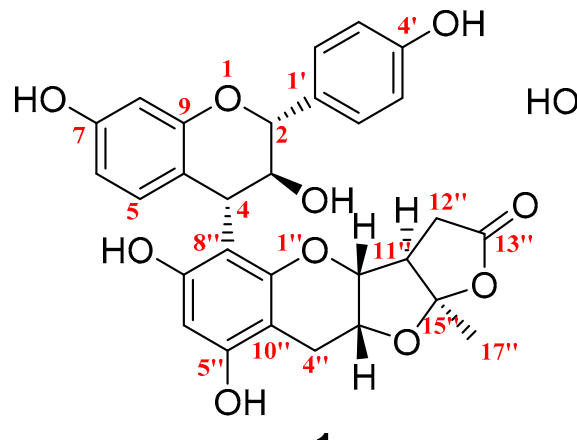

1<smiles>[R][R](O)=C[Si]</smiles>

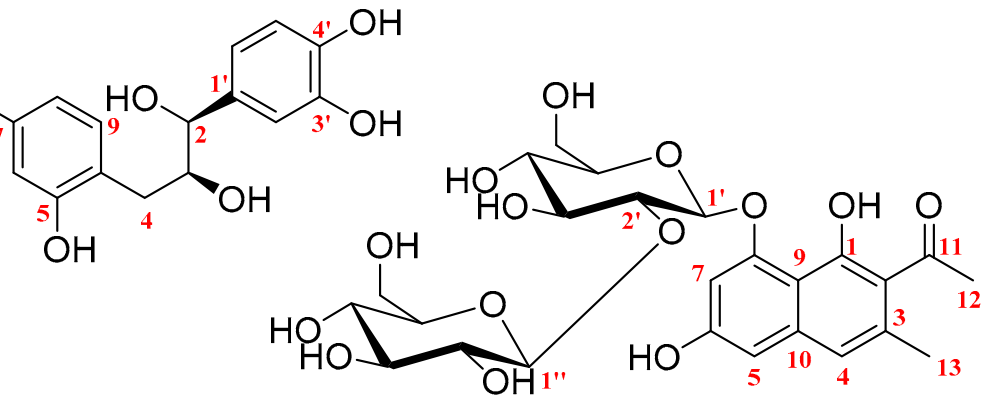

2<smiles>C1CCC(C2CCCC2)CC1</smiles>

3

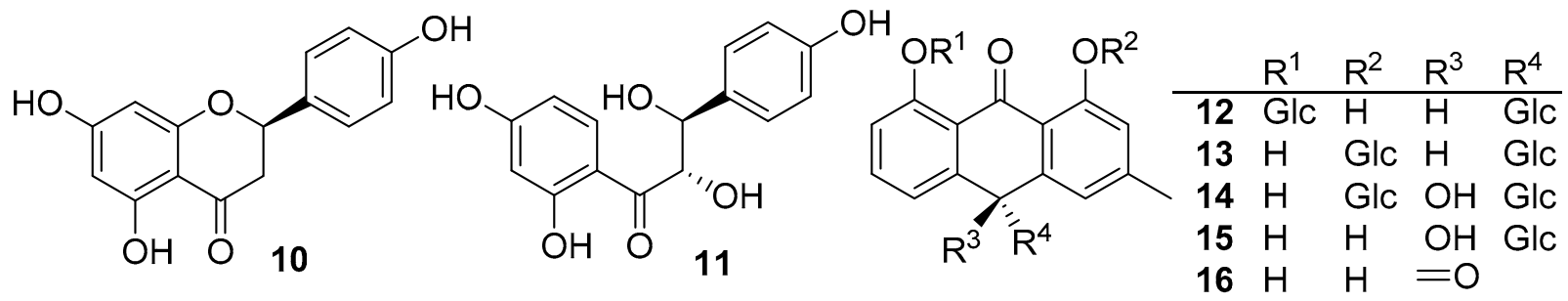

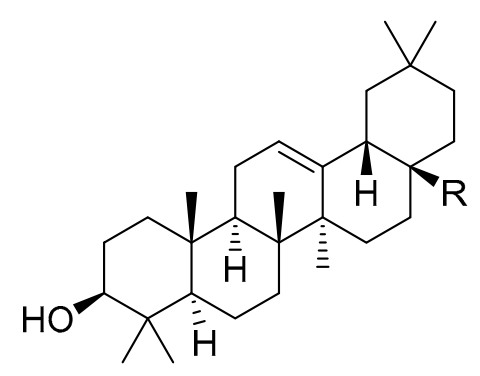<smiles></smiles><smiles>[R][R12](=O)OC([R])=O</smiles>

$17 \mathrm{R}=\mathrm{COOH}$
$18 \mathrm{R}=\mathrm{CH}_{2} \mathrm{OH}$<smiles>CCCO</smiles><smiles>[R]Oc1ccc(C(=O)O)cc1OC</smiles>

$23 \mathrm{R}=\beta$-api-(1"->2')- $\beta$-glc$24 \mathrm{R}=\mathrm{H}$<smiles>COc1c(C(C)=O)c(C)cc2cc(OC3CCCCC3)cc(OC(O)Cl)c12</smiles>

25<smiles>COc1cc([C@@H](O)[C@H](O)CO)cc(OC)c1O</smiles>

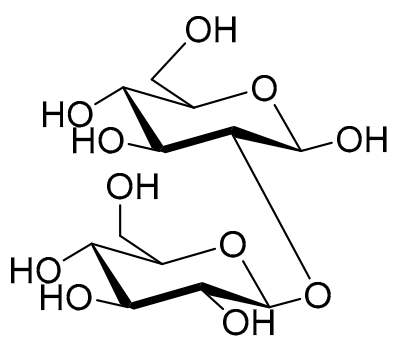

27

Figure 1. Compounds 1-28 from Cassia abbreviata. 


\section{Results and Discussion}

Compound 1 showed a molecular ion peak at $m / z 535.1590[\mathrm{M}+\mathrm{H}]^{+}$in its positive HRESIMS (Figure S18), corresponding to the molecular formula of $\mathrm{C}_{29} \mathrm{H}_{26} \mathrm{O}_{10}$. Its ${ }^{1} \mathrm{H}$ and ${ }^{13} \mathrm{C}$ NMR spectroscopic data in DMSO- $d_{6}$ (Table 1 ) exhibited 29 carbon signals, consisting of one ABX [ $\delta_{\mathrm{H}} 6.12(1 \mathrm{H}, \mathrm{d}, J=2.4 \mathrm{~Hz}, \mathrm{H}-8) ; 6.15(1 \mathrm{H}, \mathrm{dd}, J=8.4,2.4 \mathrm{~Hz}, \mathrm{H}-6) ; 6.40(1 \mathrm{H}$, $\mathrm{d}, J=8.4 \mathrm{~Hz}, \mathrm{H}-5) ; \delta_{\mathrm{C}} 102.0$ (d, C-8), 108.3 (d, C-6), 118.6 (s, C-10), 129.5 (d, C-5), 155.3 (s, C-9), $155.8(\mathrm{~s}, \mathrm{C}-7)]$, one 1,4-disubsituted [ $\delta_{\mathrm{H}} 6.76\left(2 \mathrm{H}, \mathrm{d}, J=8.5 \mathrm{~Hz}, \mathrm{H}-3^{\prime}, 5^{\prime}\right) ; 7.24(2 \mathrm{H}, \mathrm{d}$, $\left.J=8.6 \mathrm{~Hz}, \mathrm{H}-2^{\prime}, 6^{\prime}\right) ; \delta_{\mathrm{C}} 114.8\left(\mathrm{~d} \times 2, \mathrm{C}-3^{\prime}, 5^{\prime}\right), 129.3\left(\mathrm{~d} \times 2, \mathrm{C}-2^{\prime}, 6^{\prime}\right), 130.3\left(\mathrm{~s}, \mathrm{C}-1^{\prime}\right), 157.1(\mathrm{~s}$, C-4' $)]$ and one penta-substituted $\left[\delta_{\mathrm{H}} 6.09\left(1 \mathrm{H}, \mathrm{s}, \mathrm{H}-6^{\prime \prime}\right) ; \delta_{\mathrm{C}} 95.2\left(\mathrm{~d}, \mathrm{C}-6^{\prime \prime}\right), 97.4\left(\mathrm{~s}, \mathrm{C}-10^{\prime \prime}\right)\right.$, $\left.107.7\left(\mathrm{~s}, \mathrm{C}-8^{\prime \prime}\right), 151.7\left(\mathrm{~s}, \mathrm{C}-9^{\prime \prime}\right), 154.0\left(\mathrm{~s}, \mathrm{C}-5^{\prime \prime}\right), 155.4\left(\mathrm{~s}, \mathrm{C}-7^{\prime \prime}\right)\right]$ benzoic moieties, besides to one methyl $\left[\delta_{\mathrm{H}} 0.97\left(3 \mathrm{H}, \mathrm{s}, \mathrm{Me}-17^{\prime \prime}\right) ; \delta_{\mathrm{C}} 23.8\left(\mathrm{q}, \mathrm{C}-17^{\prime \prime}\right)\right]$, two $s p^{3}$ methylenes $\left[\delta_{\mathrm{H}} 2.57(\mathrm{dd}\right.$, $\left.J=17.7,5.3 \mathrm{~Hz}, \mathrm{H}-4^{\prime \prime} \beta\right), 2.67\left(\mathrm{~d}, J=17.7 \mathrm{~Hz}, \mathrm{H}-4^{\prime \prime} \alpha\right) ; 2.62\left(\mathrm{dd}, J=19.0,4.8 \mathrm{~Hz}, \mathrm{H}-12^{\prime \prime} \alpha\right)$, $\left.2.98\left(\mathrm{dd}, J=19.0,11.6 \mathrm{~Hz}, \mathrm{H}-12^{\prime \prime} \beta\right) ; \delta_{\mathrm{C}} 20.2\left(\mathrm{t}, \mathrm{C}-4^{\prime \prime}\right), 31.1\left(\mathrm{t}, \mathrm{C}-12^{\prime \prime}\right)\right]$, four oxygenated $s p^{3}$ methines $\left[\delta_{\mathrm{H}} 4.19\left(\mathrm{~d}, J=1.6 \mathrm{~Hz}, \mathrm{H}-2^{\prime \prime}\right) ; 4.26(\right.$ br. $\mathrm{t}, J=9.1 \mathrm{~Hz}, \mathrm{H}-3) ; 4.39\left(\mathrm{t}, J=2.5 \mathrm{~Hz}, \mathrm{H}-3^{\prime \prime}\right)$; $\left.4.48(\mathrm{~d}, J=9.5 \mathrm{~Hz}, \mathrm{H}-2) ; \delta_{\mathrm{C}} 69.5(\mathrm{~d}, \mathrm{C}-3), 72.8\left(\mathrm{~d}, \mathrm{C}-3^{\prime \prime}\right), 78.7\left(\mathrm{~d}, \mathrm{C}-2^{\prime \prime}\right), 82.9(\mathrm{~d}, \mathrm{C}-2)\right]$, two $s p^{3}$ methines $\left[\delta_{\mathrm{H}} 2.36\left(\mathrm{dd}, J=11.7,4.6 \mathrm{~Hz}, \mathrm{H}-11^{\prime \prime}\right) ; 4.40(\mathrm{~d}, J=9.1 \mathrm{~Hz}, \mathrm{H}-4) ; \delta_{\mathrm{C}} 40.4(\mathrm{~d}, \mathrm{C}-4)\right.$, $\left.50.2\left(\mathrm{~d}, \mathrm{C}-11^{\prime \prime}\right)\right]$, one carbonyl $\left(\delta_{\mathrm{C}} 174.5 \mathrm{~s}, \mathrm{C}-13^{\prime \prime}\right)$, and one acetalic quaternary carbon $\left(\delta_{\mathrm{C}}\right.$ $\left.115.6 \mathrm{~s}, \mathrm{C}-15^{\prime \prime}\right)$.

Table 1. ${ }^{1} \mathrm{H}(500 \mathrm{~Hz})$ and ${ }^{13} \mathrm{C}(125 \mathrm{~Hz})$ NMR spectroscopic data of 1-3 ( $\delta$ in ppm, $J$ in $\mathrm{Hz}$ within parentheses).

\begin{tabular}{|c|c|c|c|c|c|c|c|c|}
\hline \multirow{2}{*}{ No. } & \multicolumn{2}{|r|}{$1^{a}$} & \multicolumn{2}{|r|}{$1^{b}$} & \multicolumn{2}{|r|}{$2^{b}$} & \multicolumn{2}{|r|}{$3^{b}$} \\
\hline & $\delta_{\mathrm{C}}$ & $\delta_{\mathrm{H}}$ & $\delta_{\mathrm{C}}$ & $\delta_{\mathrm{H}}$ & $\delta_{\mathrm{C}}$ & $\delta_{\mathrm{H}}$ & $\delta_{\mathrm{C}}$ & $\delta_{\mathrm{H}}$ \\
\hline 1 & & & & & & & $153.7 \mathrm{C}$ & \\
\hline 2 & $82.9 \mathrm{CH}$ & $4.48(\mathrm{~d}, 9.5)$ & $84.3 \mathrm{CH}$ & $4.56(d, 9.6)$ & $80.1 \mathrm{CH}$ & 4.90 overlap & $123.3 \mathrm{C}$ & \\
\hline 3 & $69.5 \mathrm{CH}$ & $4.26(\mathrm{dd}, 9.5,9.1)$ & $72.3 \mathrm{CH}$ & $4.40(\mathrm{dd}, 9.6,9.1)$ & $67.8 \mathrm{CH}$ & 4.19 (br. t, 4.0 ) & $135.1 \mathrm{C}$ & \\
\hline 4 & $40.4 \mathrm{CH}$ & $4.40(\mathrm{~d}, 9.1)$ & $41.8 \mathrm{CH}$ & $4.58(\mathrm{~d}, 9.1)$ & $34.1 \mathrm{CH}_{2}$ & $\begin{array}{l}3.14(\mathrm{dd}, 16.2,4.2) \\
2.75(\mathrm{dd}, 16.2,3.0)\end{array}$ & $119.6 \mathrm{CH}$ & $6.86 \mathrm{~s}$ \\
\hline 5 & $129.5 \mathrm{CH}$ & $6.40(\mathrm{~d}, 8.4)$ & $130.2 \mathrm{CH}$ & $6.60(\mathrm{~d}, 8.6)$ & $156.7 \mathrm{C}$ & & $104.8 \mathrm{CH}$ & $6.64(\mathrm{~d}, 2.0)$ \\
\hline 6 & $108.3 \mathrm{CH}$ & $6.15(\mathrm{dd}, 8.4,2.4)$ & $109.9 \mathrm{CH}$ & $6.24(\mathrm{dd}, 8.6,2.4)$ & $104.0 \mathrm{CH}$ & $(\mathrm{d}, 2.4)$ & $157.9 \mathrm{C}$ & \\
\hline 7 & $155.8 \mathrm{C}$ & & $157.0 \mathrm{C}$ & & $157.8 \mathrm{C}$ & & $102.7 \mathrm{~d}$ & $6.74(\mathrm{~d}, 2.0)$ \\
\hline 8 & $102.0 \mathrm{CH}$ & $6.12(\mathrm{~d}, 2.4)$ & $103.3 \mathrm{CH}$ & $6.24(\mathrm{~d}, 2.4)$ & $109.6 \mathrm{CH}$ & $(\mathrm{dd}, 8.2,2.4)$ & $156.5 \mathrm{C}$ & \\
\hline 9 & $155.3 \mathrm{C}$ & & $156.9 \mathrm{C}$ & & $131.7 \mathrm{CH}$ & $6.90(\mathrm{~d}, 8.2)$ & $109.3 \mathrm{C}$ & \\
\hline 10 & $118.6 \mathrm{C}$ & & $120.6 \mathrm{C}$ & & $111.9 \mathrm{C}$ & & $139.5 \mathrm{C}$ & \\
\hline $1^{\prime}$ & $130.3 \mathrm{C}$ & & $131.7 \mathrm{C}$ & & $132.2 \mathrm{C}$ & & $104.8 \mathrm{CH}$ & $4.75(\mathrm{~d}, 7.7)$ \\
\hline $2^{\prime}$ & $129.3 \mathrm{CH}$ & $7.24(\mathrm{~d}, 8.6)$ & $130.3 \mathrm{CH}$ & $7.31(\mathrm{~d}, 8.5)$ & $115.4 \mathrm{CH}$ & $6.99(\mathrm{~d}, 1.7)$ & $79.8 \mathrm{CH}$ & $3.89 \mathrm{~m}$ \\
\hline $3^{\prime}$ & $114.8 \mathrm{CH}$ & $6.76(\mathrm{~d}, 8.5)$ & $116.0 \mathrm{CH}$ & $6.81(\mathrm{~d}, 8.5)$ & $145.9 \mathrm{C}$ & & $78.0 \mathrm{CH}$ & $3.34 \mathrm{~m}$ \\
\hline $4^{\prime}$ & $157.1 \mathrm{C}$ & & $158.5 \mathrm{C}$ & & $146.0 \mathrm{C}$ & & $78.2 \mathrm{CH}$ & $3.76 \mathrm{~m}$ \\
\hline $5^{\prime}$ & $114.8 \mathrm{CH}$ & $6.76(d, 8.5)$ & $116.0 \mathrm{CH}$ & $6.81(\mathrm{~d}, 8.5)$ & $116.0 \mathrm{CH}$ & $6.78(\mathrm{~d}, 8.2)$ & $71.0 \mathrm{CH}$ & $3.50 \mathrm{~m}$ \\
\hline $6^{\prime}$ & $129.3 \mathrm{CH}$ & $7.24(\mathrm{~d}, 8.6)$ & $130.3 \mathrm{CH}$ & $7.31(\mathrm{~d}, 8.5)$ & $119.4 \mathrm{CH}$ & $6.82(\mathrm{dd}, 8.2,1.7)$ & $66.9 \mathrm{CH}_{2}$ & $3.23 \mathrm{~m} ; 3.92 \mathrm{~m}$ \\
\hline $1^{\prime \prime}$ & & & & & & & $100.4 \mathrm{CH}$ & $5.23(\mathrm{~d}, 7.9)$ \\
\hline $2^{\prime \prime}$ & $78.7 \mathrm{CH}$ & $4.19(\mathrm{~d}, 1.6)$ & $81.0 \mathrm{CH}$ & $4.22(\mathrm{~d}, 2.4)$ & & & $78.4 \mathrm{CH}$ & $3.54 \mathrm{~m}$ \\
\hline $3^{\prime \prime}$ & $72.8 \mathrm{CH}$ & $4.39(\mathrm{dd}, 5.3,1.6)$ & $75.0 \mathrm{CH}$ & $4.45(\mathrm{ddd}, 5.1,2.4,1.5)$ & & & $78.0 \mathrm{CH}$ & $3.34 \mathrm{~m}$ \\
\hline $4^{\prime \prime}$ & $20.2 \mathrm{CH}_{2}$ & $\begin{array}{c}2.67(\mathrm{~d}, 17.7) \\
2.57(\mathrm{dd}, 17.7,5.3)\end{array}$ & $21.3 \mathrm{CH}_{2}$ & $\begin{array}{c}2.89(\mathrm{~d}, 17.9) \\
2.64(\mathrm{dd}, 17.9,5.1)\end{array}$ & & & $75.4 \mathrm{CH}$ & $3.25 \mathrm{~m}$ \\
\hline $5^{\prime \prime}$ & $154.0 \mathrm{C}$ & & $155.6 \mathrm{C}$ & & & & $71.0 \mathrm{CH}$ & $3.50 \mathrm{~m}$ \\
\hline $6^{\prime \prime}$ & $95.2 \mathrm{CH}$ & $6.09 \mathrm{~s}$ & $96.3 \mathrm{CH}$ & $6.09 \mathrm{~s}$ & & & $62.3 \mathrm{CH}_{2}$ & $3.74 \mathrm{~m} ; 3.93 \mathrm{~m}$ \\
\hline $7^{\prime \prime}$ & $155.4 \mathrm{C}$ & & $157.1 \mathrm{C}$ & & & & & \\
\hline $8^{\prime \prime}$ & $107.7 \mathrm{C}$ & & $109.4 \mathrm{C}$ & & & & & \\
\hline $9^{\prime \prime}$ & $151.7 \mathrm{C}$ & & $153.0 \mathrm{C}$ & & & & & \\
\hline $10^{\prime \prime}$ & $97.4 \mathrm{C}$ & & $99.6 \mathrm{C}$ & & & & & \\
\hline $11^{\prime \prime}(11)$ & $50.2 \mathrm{CH}$ & $2.36(\mathrm{dd}, 11.7,4.7)$ & $52.1 \mathrm{CH}$ & $2.39(\mathrm{dd}, 11.6,4.5)$ & & & 208.3 C & \\
\hline $12^{\prime \prime}(12)$ & $31.1 \mathrm{CH}_{2}$ & $\begin{array}{c}2.98(\mathrm{dd}, 19.0,11.7) \\
2.62(\mathrm{dd}, 19.0,4.7)\end{array}$ & $32.8 \mathrm{CH}_{2}$ & $\begin{array}{c}2.93(\mathrm{dd}, 19.2,11.6) \\
2.60(\mathrm{dd}, 19.2,4.5)\end{array}$ & & & $32.7 \mathrm{CH}_{3}$ & $2.58 \mathrm{~s}$ \\
\hline $13^{\prime \prime}(13)$ & $174.8 \mathrm{C}$ & & $177.2 \mathrm{C}$ & & & & $20.2 \mathrm{CH}_{3}$ & $2.23 \mathrm{~s}$ \\
\hline $15^{\prime \prime}$ & 115.9 C & & 118.4 C & & & & & \\
\hline $17^{\prime \prime}$ & $23.8 \mathrm{CH}_{3}$ & $0.97 \mathrm{~s}$ & $24.4 \mathrm{CH}_{3}$ & $1.10 \mathrm{~s}$ & & & & \\
\hline
\end{tabular}

${ }^{\mathrm{a}}$ Recorded in DMSO- $d_{6} \cdot{ }^{\mathrm{b}}$ Recorded in $\mathrm{CD}_{3} \mathrm{OD}$.

In the heteronuclear multiple bond connectivity $(\mathrm{HMBC})$ spectrum, a diagnostic ketal$\gamma$-lactone moiety could easily be deduced according to correlations of $\mathrm{H}-2^{\prime \prime}$ to $\mathrm{C}-3^{\prime \prime} / \mathrm{C}-15^{\prime \prime}$, $\mathrm{H}-3^{\prime \prime}$ to $\mathrm{C}-10^{\prime \prime}, \mathrm{H}-11^{\prime \prime}$ to $\mathrm{C}-3^{\prime \prime} / \mathrm{C}-13^{\prime \prime}, \mathrm{H}_{2}-12^{\prime \prime}$ to $\mathrm{C}-13^{\prime \prime} / \mathrm{C}-15^{\prime \prime}$, and $\mathrm{H}_{3}-17^{\prime \prime}$ to $\mathrm{C}-11^{\prime \prime} / \mathrm{C}-15^{\prime \prime}$, 
which by further cross peaks of $\mathrm{H}_{2}-4^{\prime \prime}$ to $\mathrm{C}-5^{\prime \prime} / \mathrm{C}-9^{\prime \prime} / \mathrm{C}-10^{\prime \prime}$ constructed the fragment of planchol A (6) [13]. Moreover, HMBC correlations of H-2 to C-1'/C-2'/C-9, H-3 to C$1^{\prime} / \mathrm{C}-2 / \mathrm{C}-4 / \mathrm{C}-10$, and $\mathrm{H}-4$ to $\mathrm{C}-5 / \mathrm{C}-9 / \mathrm{C}-10$ and the large coupling constant of H-2/H-3 $\left({ }^{3} J_{\mathrm{H} 2-\mathrm{H} 3}=9.5 \mathrm{~Hz}\right)$ could be used to establish another fragment of guibourtinidol [14]. These two fragments could be connected via C -4 and C -8 " by the key HMBC correlations of $\mathrm{H}-4$ to C- $7^{\prime \prime} / \mathrm{C}-9^{\prime \prime}$ (Figure 2). According to the large coupling constant between H-3 and $\mathrm{H}-4\left({ }^{3} \mathrm{~J}_{\mathrm{H} 3-\mathrm{H} 4}=9.1 \mathrm{~Hz}\right)$, the stereochemistry of C-4 was assumed to be $\alpha$-orientation [15]. On the basis of the above evidence and from the perspective of the biosynthetic pathway, the structure of 1 was then determined to be guibourtinidol $(4 \alpha \rightarrow 8)$ planchol A, and named cassiabrevone.

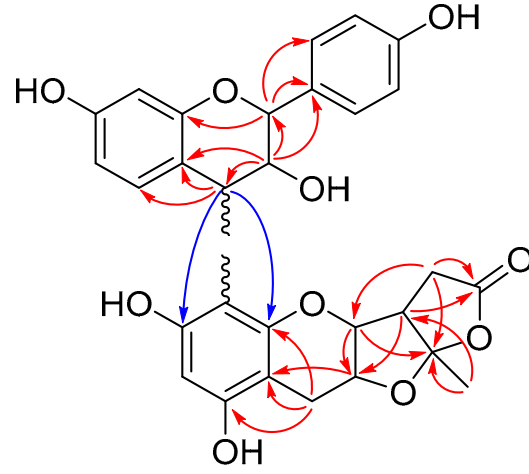

1

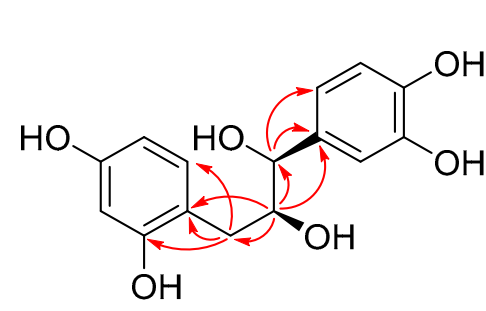

2

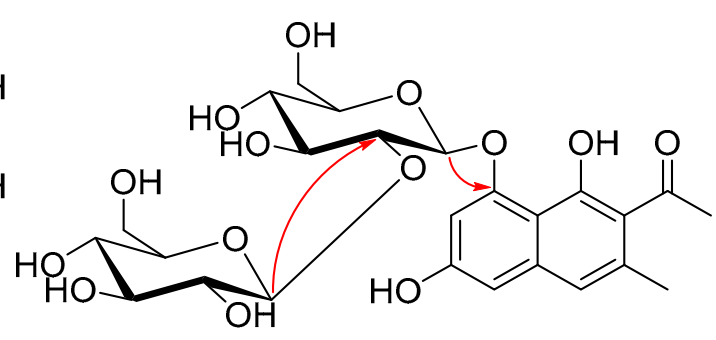

3

Figure 2. The key HMBC correlations of 1-3.

Although dimers or trimers of flavonoids were commonly found in nature, cassiabrevone is the first example of a heterodimer formed by flavanol and planchol A. It might be biosynthesized from a natural chalconol by dehydration, oxidation, and final endoattacking via neighboring group participation induced Friedel-Crafts reaction (Figure 3).

Compound 2 was assigned the molecular formula $\mathrm{C}_{15} \mathrm{H}_{16} \mathrm{O}_{6}$ from its positive HRESIMS at $m / z 293.0947[\mathrm{M}+\mathrm{H}]^{+}$. The ${ }^{1} \mathrm{H}$ and ${ }^{13} \mathrm{C}$ NMR spectroscopic data of 2 were very similar to those of epifiliferol [16,17], except that an ABX aromatic ring instead of an AX benzoic moiety was found in 2 . The assumption was confirmed by the HMBC correlation of $\mathrm{H}_{2}-4\left(\delta_{\mathrm{H}} 2.75,1 \mathrm{H}, \mathrm{dd}, J=16.2,3.0 \mathrm{~Hz}, \mathrm{H}-4 \mathrm{a} ; 3.14,1 \mathrm{H}, \mathrm{dd}, J=16.2,4.0 \mathrm{~Hz}, \mathrm{H}-4 \mathrm{~b}\right)$ to $\mathrm{C}-5\left(\delta_{\mathrm{C}}\right.$ $156.7 \mathrm{~s}) / \mathrm{C}-9\left(\delta_{\mathrm{C}} 131.7 \mathrm{~d}\right) / \mathrm{C}-10\left(\delta_{\mathrm{C}} 111.9 \mathrm{~s}\right)$. The small coupling constant between $\mathrm{H}-2$ and $\mathrm{H}-3\left({ }^{3} \mathrm{~J}_{\mathrm{H} 2 / \mathrm{H} 3}=4.0 \mathrm{~Hz}\right)$ further confirmed the erythro-configuration of 2 . Accordingly, the structure of $\mathbf{2}$ was assigned as 9-dehydroxyepifiliferol. Interestingly, it might be originated by the same biosynthetic precursor as $\mathbf{1}$, via a nucleophilic displacement reaction, followed by the oxidation reaction.

The molecular formula of compound 3 was assigned to be $\mathrm{C}_{24} \mathrm{H}_{30} \mathrm{O}_{13}$ according to its sodium adduct ion peak at $\mathrm{m} / z 557.1792[\mathrm{M}+\mathrm{H}]^{+}$, suggesting ten degrees of unsaturation. The ${ }^{1} \mathrm{H}$ and ${ }^{13} \mathrm{C}$ NMR spectra (Table 1 ) of 3 were almost the same as those of cassiaglycoside II (17) [18], except that the $\beta$-D-glucopyranosyl moiety at the C-6 position was shifted to the C-2' position. This was evidenced by the downfield shift from 74.9 to 79.8 of the C-2' position. Further confirmation could be observed by the HMBC correlations of $\mathrm{H}-1^{\prime \prime}\left(\delta_{\mathrm{H}}\right.$ $5.23,1 \mathrm{H}, \mathrm{d}, J=7.9 \mathrm{~Hz})$ to $\mathrm{C}-2^{\prime}\left(\delta_{\mathrm{C}} 79.8 \mathrm{~d}\right)$ and $\mathrm{H}-1^{\prime}\left(\delta_{\mathrm{H}} 1 \mathrm{H}, 4.75, \mathrm{~d}, J=7.7 \mathrm{~Hz}\right)$ to $\mathrm{C}-8\left(\delta_{\mathrm{C}}\right.$ $156.5 \mathrm{~s})$. By detailed analysis of its HSQC, COSY, and HMBC NMR spectroscopic data, compound 3 was then elucidated as 6-deglucopyranosyl-2'-glucopyransoyl cassiaglycoside II, and named cassiaglycoside V.

By comparison of the NMR and MS data with those published in the literature, 25 known compounds were determined to be guibourtinidol-( $4 \alpha \rightarrow 8)$-epiafzelechin (4) [15], guibourtinidol-( $4 \alpha \rightarrow 8)$-epicatechin (5) [15], planchol A (6) [13], (+)-afzelechin (7) [19], taxifolin (8) [20], dihydrokaempferol (9) [20,21], naringenin (10) [22], rhusopolyphenol 
E (11) [23], cascaroside D (12) [24], 1"-deoxyaloin B-1-O- $\beta$-D-glucopyranoside (13) [24], 10-hydroxycascaroside C (14) [24], cassialoin (15) [24], chrysophanol (16) [25], oleanolic acid (17) [26], erythrodiol (18) [26], lupeol (19) [27], $\beta$-sitosterone (20) [28], $\beta$-sitosterol (21) [29], piceatannol (22) [30], markhamioside F (23) [31], vanillic acid (24) [32], cassiaglycoside II (25) [18], (7S, 8S)-syringoylglycerol (26) [33], $\beta$-D-glucopyranosyl $(1 \rightarrow 2)-\beta$-Dglucopyranoside (27) [34], and palmitic aicd (28) [35].

The crude extract of Cassia abbreviata and all isolated compounds were assessed for their anti-HIV activity in MT4 cells infected by the reference strain HIV-1 IIIB (Figure 3). Cassiabrevone (1), guibourtinidol-( $4 \alpha \rightarrow 8)$-epiafzelechin (4), taxifolin (8), oleanolic acid (17), piceatannol (22), and palmitic acid (28) inhibited HIV-1 infection at noncytotoxic concentration and showed $\mathrm{IC}_{50}$ values ranging from 3.58 to $49.04 \mu \mathrm{M}$ (Table 2). Enfuvirtide and Plerixafor are entry inhibitors for positive controls.

Table 2. The $\mathrm{IC}_{50}$ values of compounds $1,4,8,17,22$, and 28 harboring an anti-HIV-1 activity.

\begin{tabular}{ccc}
\hline \multirow{2}{*}{ Compounds } & \multicolumn{2}{c}{ IC $_{\mathbf{5 0}}(\mu \mathrm{M})$} \\
\cline { 2 - 3 } & HIV-1 Infection $(\boldsymbol{\mu M})$ & Cytotoxicity \\
\hline CE $^{\mathrm{a}}$ & $9.98 \pm 3.88(\mu \mathrm{g} / \mathrm{mL})$ & $>1000(\mu \mathrm{g} / \mathrm{mL})$ \\
Cassiabrevone (1) & $11.89 \pm 2.14$ & $>333$ \\
Guibourtinidol-(4 $\alpha \rightarrow 8)$-epiafzelechin (4) & $15.39 \pm 9.09$ & $>333$ \\
Taxifolin (8) & $49.04 \pm 5.02$ & $>333$ \\
Oleanolic acid (17) & $7.95 \pm 2.57$ & $>333$ \\
Piceatannol (22) $_{\text {Palmitic acid (28) }}$ & $3.58 \pm 0.27$ & $>333$ \\
Enfuvirtide (T20) $^{\mathrm{b}}$ & $15.97 \pm 3.04$ & $>333$ \\
Plerixafor (AMD3100) & $0.0096 \pm 0.001$ & $>1$ \\
\hline
\end{tabular}

a CE: crude extract of Cassia abbreviate. ${ }^{\text {b }}$ Enfuvirtide and Plerixafor: positive controls. Each experiment was conducted three times and data were expressed as means \pm SD.

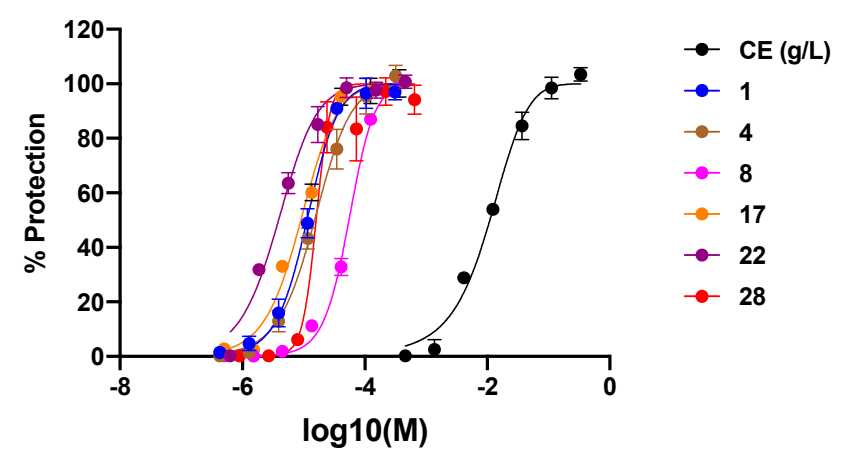

Figure 3. Protective effects of the crude extract (CE) along with compounds 1, 4, 8, 17, 22, and 28 of Cassia abbreviata against HIV-1 infection $(n=3)$.

\section{Materials and Methods}

\subsection{General Experimental Procedures}

NMR spectra were recorded on Bruker $500 \mathrm{MHz}$ spectrometer using TMS as an internal standard. The HRESIMS spectra were measured on a Waters Xevo G2 Q-TOF mass spectrometer. Optical rotations were measured with an Anton Paar MCP100 polarimeter. Chemical shifts were recorded in $\delta$ values using solvent signals DMSO- $d_{6}\left(\delta_{\mathrm{H}} 2.50 / \delta_{\mathrm{C}} 39.5\right)$ and $\mathrm{CD}_{3} \mathrm{OD}\left(\delta_{\mathrm{H}} 3.0 / \delta_{\mathrm{C}} 49.0\right)$ as references. Column chromatography $(\mathrm{CC})$ was performed on silica gel, Sephadex LH-20, and ODS (octadecyl silane).

\subsection{Plant Material}

The mature shrubs of the plant $(3 \mathrm{~kg}$ ) were collected in Makueni County, Kenya, and the identity of Cassia abbreviata was confirmed by DNA barcoding. 


\subsection{Extraction and Isolation}

Barks and roots of Cassia abbreviata were pulverized and extracted with $95 \% \mathrm{EtOH}$ four times at room temperature. The extracts were combined and concentrated to provide a crude extract ( $\mathrm{CE}, \mathrm{ca} 420 \mathrm{~g})$. Then, it was suspended in deionized water and partitioned successively with $\mathrm{CHCl}_{3}, \mathrm{EtOAc}$, and $n-\mathrm{BuOH}$, to provide an EtOAc-soluble extract $(306.7 \mathrm{~g})$ and an $n$-BuOH-soluble extract $(103.5 \mathrm{~g})$. The EtOAc extract was subjected to CC over silica gel eluting with a gradient $\mathrm{CHCl}_{3}-\mathrm{MeOH}(0 \rightarrow 100 \%)$ to obtain eight fractions (Fr.1-Fr.8). Fr.2 was further separated by ODS and Sephadex LH-20 chromatography, and finally obtained $16(58.1 \mathrm{mg})$ and $19(16.8 \mathrm{mg})$ by preparative thin-layer chromatography (prep. TLC). Compounds $20(32.7 \mathrm{mg})$ and $21(68.5 \mathrm{mg})$ were purified from Fr.3 by repeated ODS CC, Sephadex LH-20 chromatography, and prep. TLC. Fr.5 was subjected to ODS CC, Sephadex LH-20 chromatography, and prep. TLC to give $\mathbf{9}(9.3 \mathrm{mg}), \mathbf{1 0}(11.5 \mathrm{mg}), \mathbf{1 1}$ (5.1 mg), $\mathbf{1 7}(0.8 \mathrm{mg}), \mathbf{1 8}(3.5 \mathrm{mg}), \mathbf{2 4}(11.5 \mathrm{mg})$, and $\mathbf{2 8}(6.9 \mathrm{mg})$. Purification of Fr.6 by ODS and Sephadex LH-20 chromatography, followed by prep. TLC led to the isolation of $\mathbf{1}(2.4 \mathrm{mg}), \mathbf{2}(3.4 \mathrm{mg}), \mathbf{4}(7.6 \mathrm{mg}), \mathbf{5}(6.5 \mathrm{mg}), \mathbf{6}(17.8 \mathrm{mg}), 7$ (40.9 mg), 8 (17.1 mg), 15 (140.3 mg), $22(75.9 \mathrm{mg})$, and 26 (11.4 mg). The n-BuOH-soluble part was separated via ODS CC and Sephadex LH-20 chromatography, respectively. Final purification by prep. TLC obtained $\mathbf{3}(14.8 \mathrm{mg}), \mathbf{1 2}(20.0 \mathrm{mg}), \mathbf{1 3}(24.0 \mathrm{mg}), \mathbf{1 4}(22.0 \mathrm{mg}), \mathbf{2 3}(11.0 \mathrm{mg}), \mathbf{2 5}(21.0 \mathrm{mg})$, and $27(28.7 \mathrm{mg})$.

Cassiabrevone (1): pale yellow amorphous powder; $[\alpha]_{D}^{20}-12.7$ ( $\left.c 0.1, \mathrm{MeOH}\right) ;{ }^{1} \mathrm{H}$ and ${ }^{13} \mathrm{C}$ NMR data, see Table 1 ; HRESIMS $m / z 535.1590[\mathrm{M}+\mathrm{H}]^{+}\left(\right.$calcd for $\left.\mathrm{C}_{29} \mathrm{H}_{27} \mathrm{O}_{10}, 535.1599\right)$. 9-Dehydroxyepifiliferol (2): white amorphous powder; $[\alpha]_{D}^{20}-12.0(c 0.1, \mathrm{MeOH}) ;{ }^{1} \mathrm{H}$ and ${ }^{13} \mathrm{C}$ NMR data, see Table 1 ; HRESIMS $m / z 293.1009[\mathrm{M}+\mathrm{H}]^{+}\left(\right.$calcd for $\left.\mathrm{C}_{15} \mathrm{H}_{17} \mathrm{O}_{6}, 293.1020\right)$. Cassiaglycoside V (3): pale yellow amorphous powder; $[\alpha]_{D}^{20}-90.0(c 0.1, \mathrm{MeOH}) ;{ }^{1} \mathrm{H}$ and ${ }^{13} \mathrm{C}$ NMR data, see Table 1 ; HRESIMS $m / z 557.1851[\mathrm{M}+\mathrm{H}]^{+}\left(\right.$calcd for $\left.\mathrm{C}_{25} \mathrm{H}_{33} \mathrm{O}_{14}, 557.1865\right)$.

\subsection{Anti-HIV-1 Infection Bioassay}

MT4 cells were obtained through the NIH AIDS Reagent Program and cultured in RPMI 1640 (Lonza, Wijchen, the Netherlands) supplemented with 10\% heat-inactivated fetal bovine serum (Lonza, the Netherlands) and 2mM L-glutamine (Invitrogen, Gosselies, Belgium). MT-4 cells were incubated with the crude extract of Cassia abbreviatta or the tested compounds alone to assess cytotoxicity, or HIV-1 IIIB alone or a mixture of the tested extract and compounds and HIV-1 IIIB viruses to assess protection against HIV-1 infection. After five days, protection from viral infection and the cytotoxicity were evaluated in parallel using (3-(4,5-dimethylthiazol-2-yl)-2,5-diphenyltetrazolium bromide (MTT, Sigma, Liège, Belgium) by measuring $\mathrm{OD}_{540}$ and $\mathrm{OD}_{690}$ using a POLARstar Omega Plate Reader (BMG Labtech, Ortenberg, Germany). Data were normalized to cells without treatment. Values of $\mathrm{OD}_{540}-\mathrm{OD}_{690}$ were calculated to determine $\mathrm{IC}_{50}$ values in Prism. The entry inhibitors, enfuvirtide, and AMD3100 (Sigma Aldrich, Liège, Belgium), were used as positive controls.

\section{Conclusions}

From Cassia abbreviata, three new compounds, cassiabrevone, 9-dehydroxyfiliferol, and cassiaglycoside $\mathrm{V}$, were isolated along with 25 known ones. Noteworthily, cassiabrevone is the first heterodimer by flavanol guibourtinidol and tetracyclic phenolic planchol A. Moreover, six compounds showed inhibition against HIV- 1 infection with $\mathrm{IC}_{50}$ values ranging from 3 to $50 \mu \mathrm{M}$.

Supplementary Materials: The following are available online, Figures S1-S17: The 1D and 2D NMR spectra of 1-3.

Author Contributions: X.Y. isolated all compounds. X.Y., Z.H., and N.W. analyzed the chemical data and wrote the manuscript. Y.Z. performed the bioactive experiments and the barcoding analysis. M.M. provided the plant material and performed the in silico ligand-based studies. J.-C.S. designed the study with A.S. and C.S.-D. C.S.-D. analyzed the data and wrote the manuscript. All authors have read and agreed to the published version of the manuscript. 
Funding: This work was supported by the "Fonds National de la Recherche" of Luxembourg [PHD AFR grant 1189522] and the Luxembourg Institute of Health (MESR grant 20150415).

Data Availability Statement: Not available.

Acknowledgments: Authors thank Jean-Yves Servais and Morgane Lemaire for their excellent technical assistance.

Conflicts of Interest: The authors declare no conflict of interest.

\section{References}

1. Maurice, M.I. Handbook of African Medicinal Plants, 2nd ed.; CRC Press: Boca Raton, FL, USA, 1993.

2. Mongalo, N.I.; Mafoko, B.J. Cassia abbreviata Oliv, a review of its ethnomedicinal uses, toxicology, phytochemistry, possible propagation techniques and pharmacology. Afr. J. Pharm. Pharm. 2013, 7, 2901-2906. [CrossRef]

3. Ribeiro, A.; Romeiras, M.M.; Tavares, J.; Faria, M.T. Ethnobotanical survey in Canhane village, district of Massingir, Mozambique: Medicinal plants and traditional knowledge. J. Ethnobiol. Ethnomed. 2010, 6, 1-15. [CrossRef]

4. Parry, O.; Matambo, C. Some pharmacological actions of aloe extracts and Cassia abbreviata on rats and mice. Cent. Afr. J. Med. 1992, 38, 409-414.

5. Bati, K.; Kwape, T.E.; Chaturvedi, P. Anti-diabetic effects of an ethanol extract of Cassia abbreviata stem bark on diabetic rats and possible mechanism of its action: Anti-diabetic properties of Cassia abbreviata. J. Pharm. 2017, 20, 45-51. [CrossRef]

6. Leteane, M.M.; Ngwenya, B.N.; Muzila, M.; Namushe, A.; Mwinga, J.; Musonda, R.; Moyo, S.; Mengestu, Y.B.; Abegaz, B.M.; Andrae-Marobela, K. Old plants newly discovered: Cassia sieberiana D.C. and Cassia abbreviata Oliv. Oliv. root extracts inhibit in vitro HIV-1c replication in peripheral blood mononuclear cells (PBMCs) by different modes of action. J. Ethnopharmacol. 2012, 141, 48-56. [CrossRef]

7. Sobeh, M.; Mahmoud, M.F.; Abdelfattah, M.A.O.; Cheng, H.; El-Shazly, A.M.; Wink, M. A proanthocyanidin-rich extract from Cassia abbreviata exhibits antioxidant and hepatoprotective activities in vivo. J. Ethnopharmacol. 2018, 213, 38-47. [CrossRef]

8. Jobe, M.C.; Ncobela, C.N.; Kunene, N.W.; Opoku, A.R. Effects of Cassia abbreviata extract and stocking density on growth performance, oxidative stress and liver function of indigenous chickens. Trop. Anim. Health Prod. 2019, 51, 2567-2574. [CrossRef]

9. Erasto, P.; Majinda, R. Bioactive proanthocyanidins from the root bark of Cassia abbreviata. Int. J. Biol. Chem. Sci. 2011, 5, 2170-2179. [CrossRef]

10. Dangarembizi, R.; Chivandi, E.; Dawood, S.; Erlwanger, K.H.; Gundidza, M.; Magwa, M.L.; Muredzi, P.; Samie, A. Report-The fatty acid composition and physicochemical properties of the underutilised Cassia abbreviata seed oil. Pak. J. Pharm. Sci. 2015, 28, 1005-1008. [PubMed]

11. Thomford, N.E.; Dzobo, K.; Chopera, D.; Wonkam, A.; Maroyi, A.; Blackhurst, D.; Dandara, C. In vitro reversible and timedependent CYP450 inhibition profiles of medicinal herbal plant extracts Newbouldia laevis and Cassia abbreviata: Implications for herb-drug interactions. Molecules 2016, 21, 891. [CrossRef]

12. Dehmlow, E.V.; van Ree, T.; Guntenhoner, M. 2,4-Trans-,7 4'-dihydroxy-4-methoxyflavan from Cassia abbreviata. Phytochemistry 1998, 49, 1805-1806. [CrossRef]

13. Chang, J.; Case, R. Cytotoxic phenolic constituents from the root of Actinidia chinensis. Planta Med. 2005, 71, 955-959. [CrossRef]

14. Messanga, B.B.; Ghogomu, R.; Sondengam, B.L.; Martin, M.T.; Blond, A.; Brouard, J.P.; Bodo, B. Calodenin C: A new guibourtinidol-(4 $\alpha->8)$-afzelechin from Ochna calodendron. Planta Med. 1998, 64, 760-761. [CrossRef]

15. Malan, E.; Swinny, E.; Ferreira, D.; Steynberg, P. The structure and synthesis of proguibourtinidins from Cassia abbreviata. Phytochemistry 1996, 41, 1209-1213. [CrossRef]

16. Jew, S.; Lim, D.; Bae, S.; Kim, H.; Kim, J.; Lee, J.; Park, H. Enantioselective synthesis of (2R,3S)-(+)-catechin. Tetrahedron. Asymmetry 2002, 13, 715-720. [CrossRef]

17. Cangelosi, B.; Clematis, F.; Monroy, F.; Roversi, P.F.; Troiano, R.; Curir, P.; Lanzotti, V. Filiferol, a chalconoid analogue from Washingtonia filifera possibly involved in the defence against the Red Palm Weevil Rhynchophorus ferrugineus Olivier. Phytochemistry 2015, 115, 216-221. [CrossRef]

18. Nakamura, S.; Zhang, Y.; Nakashima, S.; Oda, Y.; Wang, T.; Yoshikawa, M.; Matsuda, H. Structures of aromatic glycosides from the seeds of Cassia auriculata. Chem. Pharm. Bull. 2016, 64, 970-974. [CrossRef]

19. Tai, B.H.; Trung, T.N.; Nhiem, N.X.; Ha do, T.; Van Men, C.; Duong, V.B.; Van Luong, H.; Song, S.; Bae, K.; Kim, Y.H. A new flavan-3-ol and the anti-inflammatory effect of flavonoids from the fruit peels of Wisteria floribunda. J. Asian Nat. Prod. Res. 2011, 13, 1061-1068. [CrossRef]

20. Herz, W.; Gibaja, S.; Bhat, S.V.; Srinivasan, A. Dihydroflavonols and other flavonoids of Eupatorium species. Phytochemistry 1972, 11, 2859-2863. [CrossRef]

21. Binutu, O.A.; Cordell, G.A. Constituents of Afzelia bella stem bark. Phytochemistry 2001, 56, 827-830. [CrossRef]

22. Wang, Z.H.; Li, Q.; Huang, M.; Xu, P.F.; Yang, L.P.; Zhai, Y.Y.; Zhang, Z.Z.; Zhang, W.K.; Niu, C.; Wang, H. Chemical constituents of Callicarpa macrophylla. Chem. Nat. Compd. 2020, 56, 1125-1127. [CrossRef]

23. Kim, K.H.; Moon, E.; Choi, S.U.; Kim, S.Y.; Lee, K.R. Polyphenols from the bark of Rhus verniciflua and their biological evaluation on antitumor and anti-inflammatory activities. Phytochemistry 2013, 92, 113-121. [CrossRef] 
24. Krenn, L.; Pradhan, R.; Presser, A.; Reznicek, G.; Kopp, B. Anthrone C-glucosides from Rheum emodi. Chem. Pharm. Bull. 2004, 52, 391-393. [CrossRef]

25. Prateeksha; Yusuf, M.A.; Singh, B.N.; Sudheer, S.; Kharwar, R.N.; Siddiqui, S.; Abdel-Azeem, A.M.; Fernandes Fraceto, L.; Dashora, K.; Gupta, V.K. Chrysophanol: A natural anthraquinone with multifaceted biotherapeutic potential. Biomolecules 2019, 9, 68. [CrossRef] [PubMed]

26. Shamma, M.; Rosenstock, P. The triterpenes of Heliabravoa chende. J. Org. Chem. 1959, 24, 726-728. [CrossRef]

27. Imam, S.; Azhar, I.; Hasan, M.M.; Ali, M.S.; Ahmed, S.W. Two triterpenes lupanone and lupeol isolated and identified from Tamarindus indica linn. Pak. J. Pharm. Sci. 2007, 20, 125-127. [PubMed]

28. Prachayasittikul, S.; Suphapong, S.; Worachartcheewan, A.; Lawung, R.; Ruchirawat, S.; Prachayasittikul, V. Bioactive metabolites from Spilanthes acmella Murr. Molecules 2009, 14, 850-867. [CrossRef]

29. Weihrauch, J.L.; Gardner, J.M. Sterol content of foods of plant origin. J. Am. Diet. Assoc. 1978, 73, 39-47. [PubMed]

30. Boue, S.M.; Shih, B.Y.; Burow, M.E.; Eggleston, G.; Lingle, S.; Pan, Y.B.; Daigle, K.; Bhatnagar, D. Postharvest accumulation of resveratrol and piceatannol in sugarcane with enhanced antioxidant activity. J. Agric. Food Chem. 2013, 61, 8412-8419. [CrossRef] [PubMed]

31. Kanchanapoom, T.; Kasai, R.; Yamasaki, K. Phenolic glycosides from Markhamia stipulata. Phytochemistry 2002, 59, 557-563. [CrossRef]

32. Shataer, D.; Abdulla, R.; Ma, Q.L.; Liu, G.Y.; Aisa, H.A. Chemical composition of extract of Corylus avellana Shells. Chem. Nat. Compd. 2020, 56, 338-340. [CrossRef]

33. Matsuura, H.; Miyazaki, H.; Asakawa, C.; Amano, M.; Yoshihara, T.; Mizutani, J. Isolation of $\alpha$-glusosidase inhibitors from hyssop (Hyssopus officinalis). Phytochemistry 2004, 65, 91-97. [CrossRef] [PubMed]

34. Li, N.; Li, X.; Hou, B.L.; Meng, D.L. New disaccharoside from Camptosorus sibiricus Rupr. Nat. Prod. Res. 2008, 22, 1379-1383. [CrossRef] [PubMed]

35. Hamid, A.A.; Aiyelaagbe, O.O.; Negi, A.S.; Kaneez, F.; Luqman, S.; Oguntoye, S.O.; Kumar, S.B.; Zubair, M. Isolation and antiproliferative activity of triterpenoids and fatty acids from the leaves and stem of Turraea vogelii Hook. f. ex benth. Nat. Prod. Res. 2019, 33, 296-301. [CrossRef] [PubMed] 